\title{
Toll-like receptor 2-mediated induction of human beta-defensin 2 expression by Leptospira interrogans in human kidney cells
}

\author{
Naharuthai Inthasin, ${ }^{1}$ Chawikan Boonwong, ${ }^{2}$ Sutthicha Matamnan, ${ }^{2}$ Jintapa Sueasuay, ${ }^{1}$ Patimaporn Wongprompitak, ${ }^{1}$ \\ Wiwit Tanttibhedhyangkul, ${ }^{1}$ Pattama Ekpo ${ }^{1,2}$
}

\begin{abstract}
Background: Leptospirosis is a zoonotic disease caused by Leptospira interrogans. Severe leptospirosis is often accompanied by kidney dysfunction caused by chronic infection. The kidney pathology involves bacterial invasion and inflammation caused by pro-inflammatory cytokines. Human beta defensins (hBDs) are antimicrobial peptides induced by microbial infection and/or pro-inflammatory cytokines. One function of hBDs is the recruitment of immune cells that leads to inflammation. However, the expression of hBDs by kidney epithelium in response to pathogenic Leptospira has never been investigated.
\end{abstract}

Objective: To determine the expression of hBDs in human kidney epithelium responses to Leptospira.

Methods: Human kidney cells were infected with Leptospira interrogans serovar Autumnalis in the presence or absence of anti-TLR2 neutralizing antibody (Ab) for 6 hours. TLR2, hBDs and pro-inflammatory cytokines mRNA expressions were analyzed by quantitative polymerase chain reaction (qPCR).

Results: Pathogenic Leptospira upregulated the expressions of pro-inflammatory cytokines and hBD2, but not TLR2, $h B D 1$ and $h B D 3$ in kidney cells. The expressions of $h B D 2$ and pro-inflammatory cytokines were inhibited in the presence of anti-hTLR2 neutralizing Ab.

Conclusions: Our results provide the first evidence that pathogenic Leptospira induces $h B D 2$ expression in kidney cells. The expressions of pro-inflammatory cytokines and $h B D 2$ in the cells in response to pathogenic Leptospira are regulated by TLR2. Pro-inflammatory cytokines and $h B D 2$ might be play role in recruitment of immune cells to the kidney and contribute to the development of inflammation-mediated tissue damage in the kidney. However, further study is needed to improve the understanding of the role of these molecules in immune response activation.

Key words: TLR2, leptospirosis, kidney epithelium, human beta-defensins, Leptospira

\section{From:}

${ }^{1}$ Department of Immunology, Faculty of Medicine Siriraj Hospital, Mahidol University, Bangkok, Thailand

${ }^{2}$ Research Department, Faculty of Medicine Siriraj Hospital,

Mahidol University, Bangkok, Thailand

Corresponding author:

Pattama Ekpo

Department of Immunology and Research Department

Faculty of Medicine Siriraj Hospital, Mahidol University,

2 Wanglang Road, Bangkok Noi, Bangkok 10700, Thailand

E-mail: pattama.ekp@mahidol.ac.th

\section{Introduction}

The innate immune response plays an important role in recognizing pathogens and stimulating the production of pro-inflammatory cytokines. It also affects host defense via the induction of antimicrobial peptides. Defensins, which belong to a family of antimicrobial peptides, provide protection against a broad spectrum of pathogens, viruses, bacteria, and fungi. ${ }^{1-4}$ In humans, defensins are classified into two groups: $\alpha$ - and $\beta$-defensins. ${ }^{5}$ Human $\beta$-defensin-2 (hBD2) is detected in the epithelium of almost the entire human body, including renal epithelium. ${ }^{6-14}$ Toll-like receptor 2 (TLR2) is the major pattern recognition receptor (PRR) that recognizes and monitors the host for the presence of Leptospira. ${ }^{15-20}$ Our research group previously demonstrated that human TLR2 
regulates $h B D 2$ expression in oral mucosal epithelium induced by $L$. interrogans. ${ }^{21}$ The expression of $h B D 2$ at the portal of entry acts to neutralize the virulence or prevent the invasion of the microbes. ${ }^{22}$ However, overexpression of hBDs can result in diseases such as psoriasis and kidney disease. ${ }^{23-26}$ The kidney is a target organ of leptospiral infection; however, a connection between Leptospira, TLR2 recognition/activation, and hBD2 production has not been established in human kidney cells. Understanding the mechanisms that regulate the pro-inflammatory cytokine and hBD response are important for controlling the disease. Accordingly, the aim of this study was to investigate the role of TLR2 in mediating the production of cytokines and hBDs in the kidney epithelium response to a leptospiral infection.

\section{Methods \\ Bacterial culture and preparation}

L. interrogans serovar Autumnalis was isolated from clinical specimens obtained from a patient admitted to Siriraj Hospital, Bangkok, Thailand. Siriraj Hospital is Thailand's largest university-based national tertiary referral center. The protocol for this study was approved by the Siriraj Institutional Review Board (COA no 639/2551[EC2]) of the Faculty of Medicine Siriraj Hospital, Mahidol University, Bangkok, Thailand. The bacteria were cultured in Ellinghausen-McCullough-Johnson -Harris (EMJH) medium supplemented with $10 \%$ of leptospiral enrichment (HiMedia Laboratories, Mumbai, India) at $30^{\circ} \mathrm{C}$. On the day of infection, the bacteria were washed by centrifugation at $10,000 \times \mathrm{g}$ for 10 minutes in sterile phosphate-buffered saline (PBS). After being washed twice, the pellet was resuspended in cell culture medium and infected into cultivated kidney epithelium.

\section{Human kidney epithelial cell cultivation and stimulation}

A human kidney epithelium (HK2) cell line cultured in Dulbecco's Modified Eagle Medium (DMEM; Life Technology, CA, USA) supplemented with $10 \%$ heat-inactivated fetal bovine serum (FBS; GE Healthcare, IL, USA), $50 \mathrm{U} / \mathrm{ml}$ of penicillin, and $50 \mu \mathrm{g} / \mathrm{ml}$ of streptomycin was incubated in a humidified incubator at $37^{\circ} \mathrm{C}$ with $5 \% \mathrm{CO}_{2}$. One hundred microliters of the cells at quantity of $2 \times 10^{4}$ were plated onto each well of a 96-well plate. After incubation overnight, the culture medium was removed and replaced with $100 \mathrm{MOI}$ of Leptospira or with 40 MOI of heat killed Listeria monocytogenes (HKLM; a TLR2 ligand) suspended in DMEM without antibiotics. In some experiments, the cells were pretreated with anti-hTLR2 neutralizing antibody (Ab) or its isotype control $\mathrm{Ab}$ at the same concentration (final concentration of $5 \mu \mathrm{g} / \mathrm{ml}$; InvivoGen, CA, USA) for 1 hour at $37^{\circ} \mathrm{C}$ with $5 \%$ $\mathrm{CO}_{2}$ before adding the Leptospira. After a 6-hour stimulation with the bacteria at $37^{\circ} \mathrm{C}$ with $5 \% \mathrm{CO}_{2}$, the supernatant was removed and the infected cell was collected by adding $350 \mu \mathrm{l}$ of lysis buffer (Qiagen, Hilden, Germany). The experiment was performed in duplicate at least three times independent experiments. The statistical different at $p$-value $<0.05$ of mean of three biological replicated were analyzed together by paired $t$-test.

\section{RNA extraction and total RNA quantification}

Total RNA was extracted from the infected cells using RNeasy Mini Kit (Qiagen, Hilden, Germany). The genomic DNA was removed by the DNA removing column included in the kit. Then, $50-100 \mathrm{ng} / \mu \mathrm{l}$ of extracted RNA was reversed to cDNA by Superscript III $^{\circledast}$ reverse transcriptase enzyme (Life Technologies, St Paul, MN, USA), following the manufacturer's protocol.

\section{Analysis of $m R N A$ expression by $R T-q P C R$}

The PCR master mix consisted of $1 \mathrm{X}$ iTaq SYBR Green Master Mix (Bio-Rad Laboratories, CA, USA), $0.5 \mu \mathrm{M}$ of forward and reverse primers, ${ }^{21}$ and $5 \mu \mathrm{l}$ of $\mathrm{cDNA}$. The primer sequences used in the RT-qPCR analysis are detailed in Table 1. The PCR was performed under the following conditions: enzyme activation at $95^{\circ} \mathrm{C}$ for 10 minutes and 40 cycles of denaturation at $95^{\circ} \mathrm{C}$ for 10 seconds; annealing at $59^{\circ} \mathrm{C}$ for 15 seconds; and extension at $72^{\circ} \mathrm{C}$ for 5 seconds with fluorescence detection. The quantification cycle $(\mathrm{Cq})$ of $h B D 1-3$, pro-inflammatory cytokines $(I L-1 \beta, I L-6, I L-8$, and TNF- $\alpha$ ) and hTLR2 mRNA were quantified and normalized with the reference gene $(G A P D H)$. The delta Cq of the stimulated cells were then normalized with the delta $\mathrm{Cq}$ of the unstimulated cells. The relative fold change of mRNA expression was calculated with the $2^{-\Delta \Delta \mathrm{Cq}}$ formula.

Table 1. The primer sequences used for RT-qPCR analysis, their corresponding melting temperatures, and the sizes of PCR products

\begin{tabular}{|c|c|c|c|c|}
\hline Gene & Sequence $\left(5^{\prime} \rightarrow 3^{\prime}\right)$ & $\begin{array}{c}\operatorname{Tm} \\
\left({ }^{\circ} \mathrm{C}\right)\end{array}$ & $\begin{array}{l}\text { PCR product } \\
\text { (bp) }\end{array}$ & $\begin{array}{c}\text { Accession } \\
\text { Number }\end{array}$ \\
\hline IL-1 $\beta \_F$ & TGGAGCAACAAGTGGTGT & 56 & 157 & NM_000576.3 \\
\hline IL-1 $\beta \_\mathrm{R}$ & TTGGGATCTACACTCTCCAGC & 58 & & \\
\hline IL-6_F & CGGGAACGAAAGAGAAGCTCTA & 60 & 68 & NM_000600.5 \\
\hline IL-6_R & GGCGCTTGTGGAGAAGGAG & 61 & & \\
\hline IL-8_F & GCCAACACAGAAATTATTGTAAAGCTT & 56 & 112 & NM_000584 \\
\hline IL-8_R & AATTCTCAGCCСТCTTCAAAAACTT & 55 & & \\
\hline TNF- $a \_F$ & CCCAGGCAGTCAGATCATCTTC & 60 & 75 & NM_000594.4 \\
\hline TNF-a_R & CAGCTTGAGGGTTTGCTACAAC & 60 & & \\
\hline
\end{tabular}


Table 1. (Continued)

\begin{tabular}{rlccc} 
Gene & \multicolumn{1}{c}{ Sequence $\left(5^{\prime} \rightarrow 3^{\prime}\right)$} & $\begin{array}{c}\text { Tm } \\
\left({ }^{\circ} \mathbf{C}\right)\end{array}$ & $\begin{array}{c}\text { PCR product } \\
(\mathbf{b p})\end{array}$ & $\begin{array}{c}\text { Accession } \\
\text { Number }\end{array}$ \\
\hline hBD1_F & CTGCTGTTTACTCTCTGCTTACTTTT & 62 & 107 & NM_005218 \\
hBD1_R & CCTCCACTGCTGACGCA & 50 & & \\
hBD2_F & GATCCTGTTACCTGCCTTAAGAGT & 62 & 83 & NM_001205266 \\
hBD2_R & CCACAGGTGCCAATTTGTTTATACC & 60 & & \\
hBD3_F & GTCATGGAGGAATCATAAACACATTACAG & 56 & 100 & NM_018661 \\
hBD3_R & CCGATCTGTTCCTCCTTTGGA & 62 & & \\
TLR2_F & GTACCTGTGGGGCTCATTGT & 57 & 178 & NM_003264 \\
TLR2_R & TACCATTGCGGTCACAAGAC & 55 & & \\
GAPDH_F & ACAGCCTCAAGATCATCAGCA & 59 & 119 & NM_002046 \\
GAPDH_R & GATGGCATGGACTGTGGTCA & 60 & & \\
\hline
\end{tabular}

Abbreviations: RT-qPCR, reverse transcription quantitative polymerase chain reaction; Tm, melting temperature; bp, base pair

\section{Results}

Induction of hBD and pro-inflammatory cytokine expressions in response to Leptospira interrogans in $\mathrm{HK} 2$ cells

Pro-inflammatory cytokines including $I L-1 \beta, I L-6, I L-8$, and TNF- $\alpha$ were reported to be involved in kidney pathology and severe leptospirosis. ${ }^{23-25}$ Therefore, in this study we determined whether these pro-inflammatory cytokines in the cultivated kidney epithelium responded to the leptospiral infection. HK2 cells were infected with L. interrogans for $6 \mathrm{~h}$. The infected cells were collected and evaluated for $h B D$ and

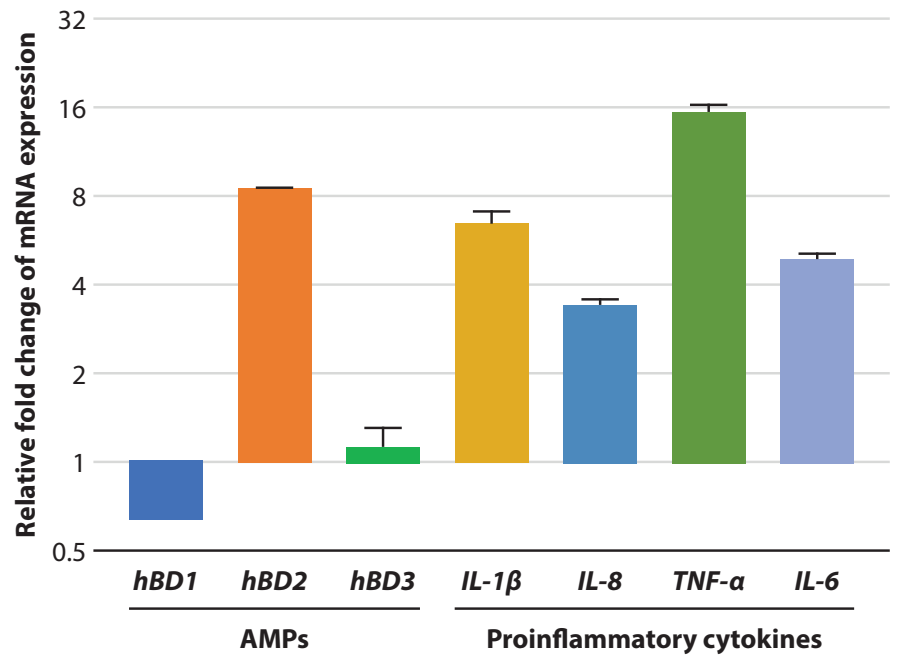

Figure 1. Human beta-defensin (hBD) and pro-inflammatory cytokine expressions in cultivated kidney epithelium response to 100 multiplicity of infection (MOI) of Leptospi$r a$. The relative fold change of mRNA expression was normalized with $G A P D H$ gene and unstimulated cell by $2^{-\triangle \triangle C q}$ method. The graph shows mean \pm SEM of one representative from three biological replicated experiments. Unstimulated cell is the cultivated kidney epithelium response to the cell culture medium. pro-inflammatory cytokine expressions by RT-qPCR. We found that $L$. interrogans induced the increasing of the proinflammatory cytokines $I L-1 \beta, I L-6, I L-8$, and $T N F-\alpha$ and of $h B D 2$, but not of $h B D 1$ and $h B D 3$ (Figure 1). The mean fold change of mRNA expression of three replicated experiments of $I L-1 \beta, I L-6, I L-8, T N F-\alpha$, and $h B D 2$ were $5.48 \pm 0.5$, $6.53 \pm 2.34,4.69 \pm 1.16,13.04 \pm 2.53$, and $12.78 \pm 3.745$, respectively. This supports that cultivated kidney epithelium has the ability to respond to a leptospiral infection by increasing the expression of $h B D 2$ and pro-inflammatory cytokines.

hTLR2 mediated pro-inflammatory cytokine and hBD2 expressions in $\mathrm{HK} 2$ cells

We first examined the optimal concentration of the antihTLR2 neutralizing $A b$ and found that the $A b$ at the final concentration of $5 \mu \mathrm{g} / \mathrm{ml}$ was sufficient to inhibit $I L-8 \mathrm{mRNA}$ expression from HKLM-stimulated HK2 cells (Figure 2). Therefore, we used the final concentration of $5 \mu \mathrm{g} / \mathrm{ml} \mathrm{Ab}$ in the next experiment.

As TLR2 is a major human PRR that recognizes Leptospira, we investigated whether the expressions of $h B D 2$ and pro-inflammatory cytokines in $\mathrm{HK} 2$ cells are mediated by hTLR2. The data in figure 3 indicate that hTLR2 was involved in the expressions of $h B D 2$ and pro-inflammatory cytokines $(I L-1 \beta, I L-6, I L-8$, and TNF- $\alpha)$. Since, the expressions of these mRNA were significantly reduced in the $\mathrm{Ab}$ pre-treated HK2 cells before being infected with Leptospira. This experiment indicated that hTLR2 was involved in the expressions of $h B D 2$ and pro-inflammatory cytokines in Leptospira-infected HK2 cells.

We further investigated the expression of hTLR2 in HK2 cells and found that the fold of TLR2 mRNA expression in Leptospira-infected HK2 cells did not differ from unstimulated HK2 cells (Figure 4). 


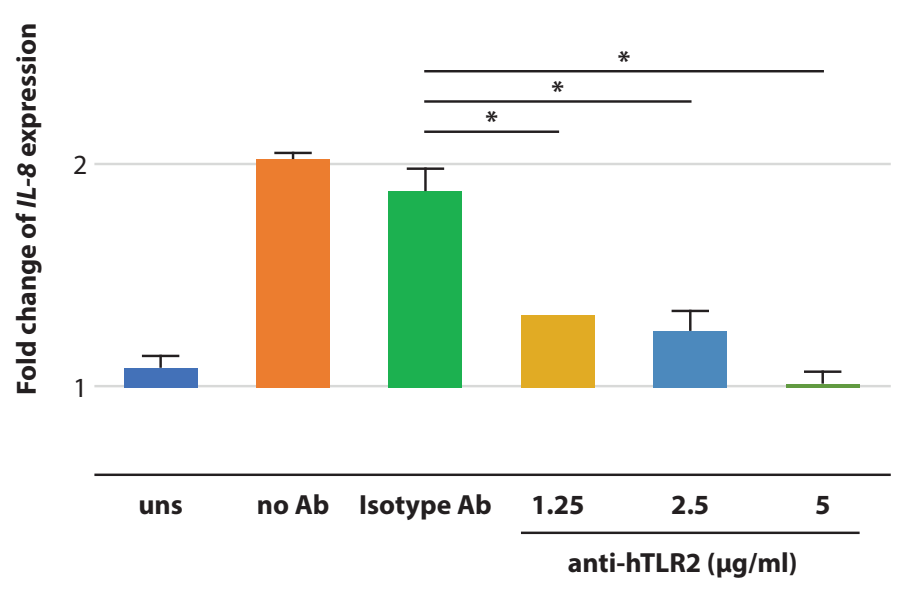

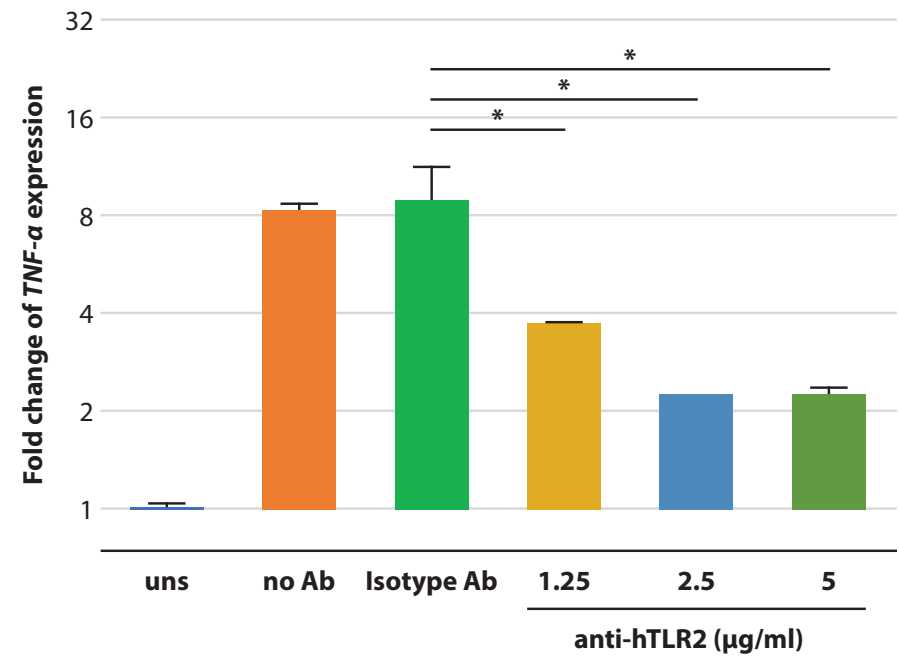

Figure 2. The neutralizing activity of anti-hTLR2 Ab to $I L-8$ and TNF- $\alpha$ mRNA expressions from HKLM-stimulated HK2 cells. HK2 cells were pre-incubated with various concentrations of the anti-hTLR2 Ab (1.25, 2.5, $5 \mu \mathrm{g} / \mathrm{ml})$ or isotype control Ab $(5 \mu \mathrm{g} / \mathrm{ml})$ for $1 \mathrm{~h}$ before stimulation with the TLR2 ligand (HKLM). The relative fold change of mRNA expression was normalized with $G A P D H$ gene and unstimulated cell by $2^{-\triangle \triangle C q}$ method. The graph shows mean \pm SEM of one representative experiment that was performed in duplicate. Unstimulated cell is the HK2 cell response to the cell culture medium.

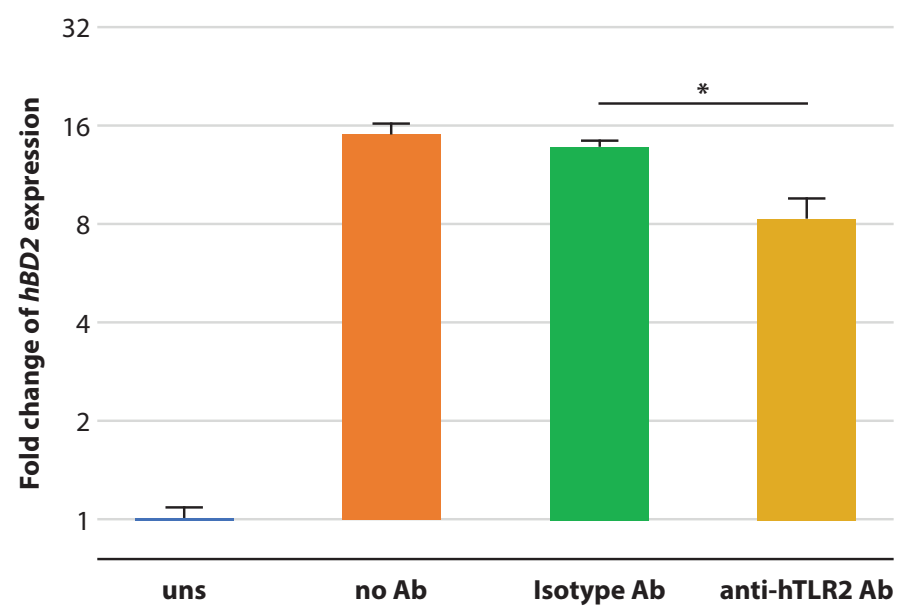

16

16
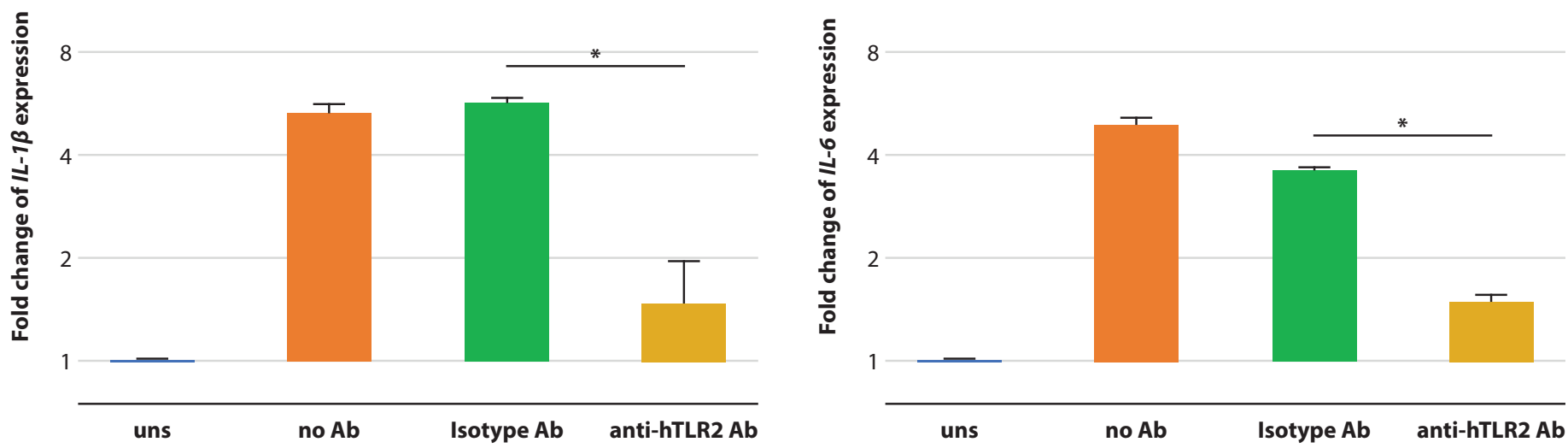

Figure 3. Effect of anti-hTLR2 neutralizing Ab on $L$. interrogans stimulated pro-inflammatory cytokine and $h B D 2$ expressions. Cultivated kidney epithelium was pre-incubated with or without anti-hTLR2 neutralizing or isotype control Ab for 1 hour before infection, and then stimulated with L. interrogans at MOI 100. The relative fold change of mRNA expression was normalized with GAPDH gene and unstimulated cell by $2^{-\triangle \triangle \mathrm{Cq}}$ method. The graph shows mean \pm SEM of one representative experiment that was performed in duplicate. The statistical different of mean between isotype Ab and anti-hTLR2 Ab of three biological replicated were analyzed together by paired $t$-test. ( ${ }^{\star}$ statistically significant difference at $p$-value $<0.05$ ). Unstimulated cell is the HK2 cell response to the cell culture medium. 
16

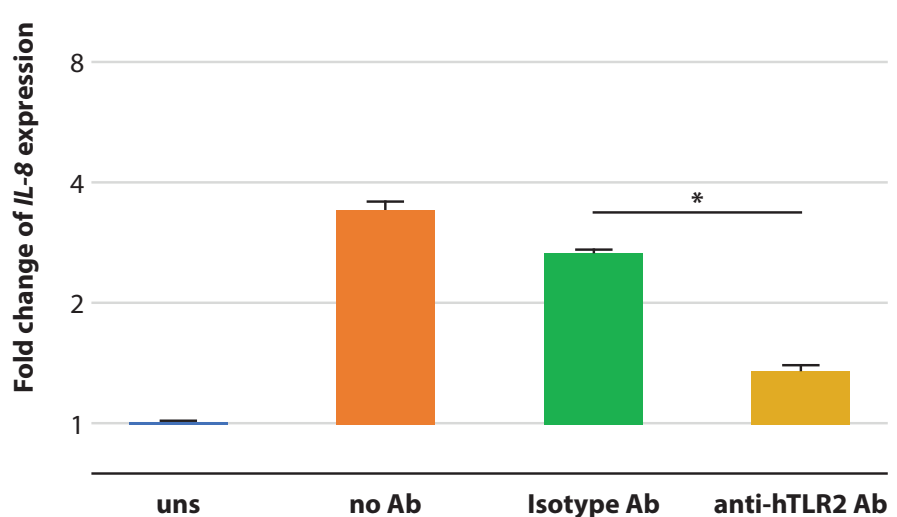

Figure 3. (Continued)

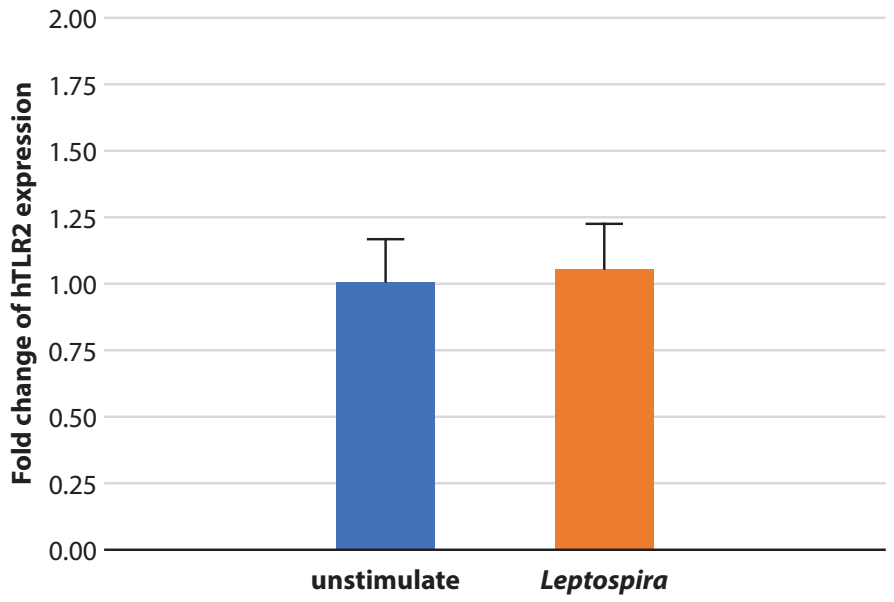

Figure 4. Human TLR2 expression in unstimulated and Leptospira-infected HK2 cells. The relative fold change of TLR2 mRNA expression was normalized with GAPDH gene and unstimulated $\mathrm{HK} 2$ cell by $\Delta \Delta \mathrm{Cq}$ method. Unstimulated cell is the HK2 cell response to the cell culture medium.

\section{Discussion}

We focused on the innate immune response in the kidneys which are a major target organ of leptospirosis. The pathology of kidney leptospirosis caused by bacterial invasion and chronic inflammation has been well described. ${ }^{26-28}$ The proinflammatory cytokines and chemokine which cause inflammation are induced to express in kidneys by pathogenic leptospires. ${ }^{29}$ However, the induction of antimicrobial peptide (AMP) expression in response to Leptospira infection in kidneys has never been studied.

AMP directly kill microbes or function as a chemotactic factor that results in the recruitment of immune cells and inflammation. The human beta defensins (hBDs) were studied because they can be detected in the epithelium of almost the entire human body, including renal epithelium. Overexpression of hBDs can result in diseases that include psoriasis and kidney disease. ${ }^{22,30}$ In an in vivo study in hamsters, a susceptible animal, ${ }^{31}$ there was significantly upregulated expressions of cytokine $I L-1 \beta$, and chemokines MIP-1 $\alpha / C C L 3$ and IP-10/ CXCL-10 in response to virulent Leptospira borgpetersenii

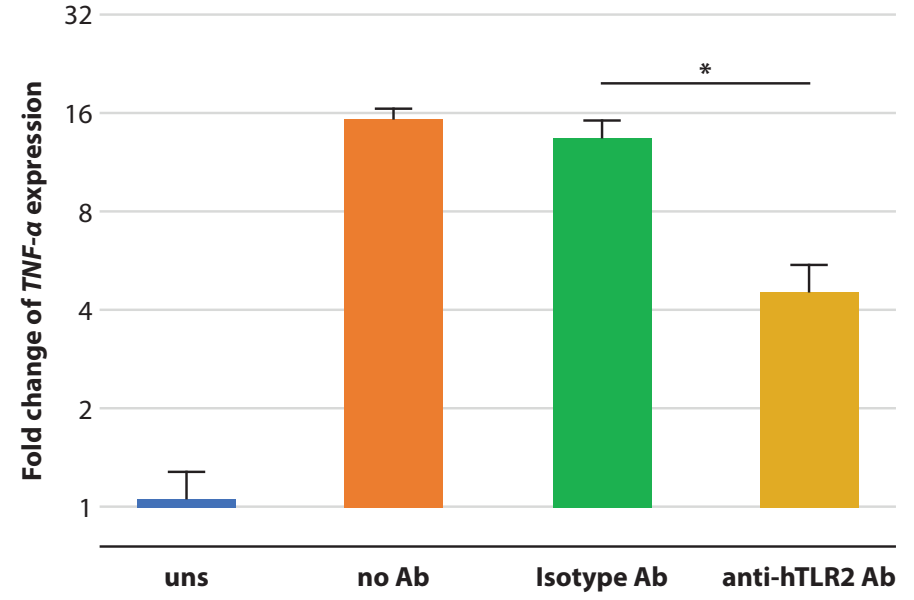

serogroup Ballum isolate B3-13S in the kidneys. However, that study did not examine hBD2 expression. This AMP may act as chemotactic factor or antimicrobial host defense in kidneys. ${ }^{32}$ Therefore, further study is needed to improve our understanding of the role of $h B D 2$ in immune response activation.

TLR2 is the most important TLR in response to Leptospira infection; however, a connection between Leptospira, TLR2 recognition/activation, pro-inflammatory cytokine, and $\mathrm{hBD}$ productions has not been established in human kidney cells.

We tested the responsiveness of kidney epithelial cells that were found to produce increased amounts of $I L-1 \beta, I L-6, I L$ $8, T N F-\alpha$, and $h B D 2$ (but not $h B D 1$ and $h B D 3$ ) in response to leptospiral infection via a TLR2-dependent mechanism. While anti-TLR2 neutralizing Ab could significantly reduce the expression of hBD-2 and pro-inflammatory cytokines, there may be other PRRs that also play this role. This is plausible because anti-TLR2 neutralizing Ab could not completely inhibit the expression of hBD-2 and pro-inflammatory cytokines.

Renal-associated TLR2 is an important initiator of the inflammatory response. ${ }^{20,32,33}$ TLR2 is mainly expressed by tubular cells, and is enhanced upon infection. ${ }^{34}$ In this study, TLR2 expression at the transcriptional level from HK2 cells at an acute phase of Leptopsira infection was not significantly different from unstimulated cells. Human TLR2 is the main PRR recognizing Leptospira lipopolysaccharide (LPS) and other outer membrane proteins like LipL32, which is the major lipoprotein of pathogenic leptospires. ${ }^{15-19}$ Our findings link leptospiral infection, TLR2 activation, and the induction of both pro-inflammatory cytokines and $h B D 2$ using human kidney epithelial cells.

$I L-8$ is a neutrophil chemoattractant that may recruit the immune cells to the kidney. ${ }^{22,35,36}$ The main evidence of leptospirosis infection is interstitial nephritis associated with intense leukocytic infiltration of neutrophils and monocytes. ${ }^{37}$ In addition, $h B D 2$ acts via the chemokine receptor CCR6 to attract immature dendritic cells and memory $\mathrm{T}$ cells to the kidney. ${ }^{17,20,22,38}$ These processes might facilitate the development of adaptive immune responses that can also increase inflammation in the kidney. 
Although $h B D 2$ was initially considered to be an antimicrobial peptide, an advanced study revealed that $h B D 2$ has multiple functions. ${ }^{39}$ However, its role in the pathology of kidney disease caused by leptospirosis is unclear. During the infection processes of the kidney epithelium, $h B D 2$ is expressed by the effect of the infection mediated to TLR2 activation. This might be associated with the disease severity. There are some limitations in this study. Only one kidney cell line was used; therefore, the results may vary in other human kidney cell lines, primary cells or in vivo study. In addition, we determined hBD-2 and pro-inflammatory cytokines only at the transcription level. The transcription results may not be the same as protein expression. An improved understanding of the role of TLR-mediated antimicrobial expression would provide greater insight on the mechanisms of inflammation-mediated kidney tissue damage caused by leptospiral infection. Further study is needed on the role of these molecules in immune response activation.

\section{Conflicts of interest declaration}

All authors declare that they have no personal or professional conflicts of interest related to this research, and they have not received financial support from the companies that produce and/or distribute the drugs, devices, or materials described in this report.

\section{Funding disclosure}

This study was funded by a grant from the Faculty of Medicine Siriraj Hospital, Mahidol University, Bangkok, Thailand.

\section{Author contributions}

All authors contributed to the data analysis and the writing of this paper, gave final approval of the version to be published, and agreed to be accountable for all aspects of the work.

\section{References}

1. Weinberg A, Krisanaprakornkit S, Dale BA. Epithelial Antimicrobial Peptides: Review and Significance for Oral Applications. Crit Rev Oral Biol Med. 1998;9(4):399-414.

2. Zasloff M. Antimicrobial peptides of multicellular organisms. Nature. 2002;415(6870):389-95.

3. Bachère E, Gueguen Y, Gonzalez M, De Lorgeril J, Garnier J, Romestand B. Insights into the anti-microbial defense of marine invertebrates: the penaeid shrimps and the oyster Crassostrea gigas. Immunol Rev. 2004; 198(1):149-68.

4. Hancock REW, Brown KL, Mookherjee N. Host defence peptides from invertebrates - emerging antimicrobial strategies. Immunobiol. 2006; 211(4):315-22.

5. Ganz T, Lehrer RI. Antimicrobial peptides of vertebrates. Current Opinion in Immunol. 1998;10(1):41-4.

6. McNamara NA, Van R, Tuchin OS, Fleiszig SMJ. Ocular Surface Epithelia Express mRNA for Human Beta Defensin-2. Exp Eye Res. 1999;69(5): 483-90

7. Garreis F, Schlorf T, Worlitzsch D, Steven P, Bräuer L, Jäger K, et al. Roles of human $\beta$-defensins in innate immune defense at the ocular surface: arming and alarming corneal and conjunctival epithelial cells. Histochem Cell Biol. 2010;134(1):59-73.

8. Bals R, Goldman MJ, Wilson JM. Mouse $\beta$-Defensin 1 Is a Salt-Sensitive Antimicrobial Peptide Present in Epithelia of the Lung and Urogenital Tract. Infect Immun. 1998;66(3):1225-32.
9. Doss M, White MR, Tecle T, Hartshorn KL. Human defensins and LL-37 in mucosal immunity. J Leukoc Biol. 2010;87(1):79-92.

10. Hertz CJ, Wu Q, Porter EM, Zhang YJ, Weismüller K-H, Godowski PJ, et al. Activation of Toll-Like Receptor 2 on Human Tracheobronchial Epithelial Cells Induces the Antimicrobial Peptide Human $\beta$ Defensin-2. J Immunol. 2003;171(12):6820-6.

11. Garcia-Lopez G, Flores-Espinosa P, Zaga-Clavellina V. Tissue-specific human beta-defensins (HBD)1, HBD2, and HBD3 secretion from human extra-placental membranes stimulated with Escherichia coli. Reprod Biol Endocrinol. 2010;8(1):146.

12. Hill DR, Kessler SP, Rho HK, Cowman MK, de la Motte CA. Specific-sized Hyaluronan Fragments Promote Expression of Human $\beta$-Defensin 2 in Intestinal Epithelium. J Biol Chem. 2012;287(36):30610-24.

13. Gursoy UK, Könönen E. Understanding the roles of gingival beta -defensins. J Oral Microbiol. 2012;4(1):15127.

14. Kesting MR, Mueller C, Wagenpfeil S, Stoeckelhuber M, Steiner T, Bauer F, et al. Quantitative comparison of the expression of antimicrobial peptides in the oral mucosa and extraoral skin. Br J Oral Maxillofac Surg. 2012;50(5):447-53.

15. Werts C, Tapping RI, Mathison JC, Chuang TH, Kravchenko V, Saint Girons I, et al. Leptospiral lipopolysaccharide activates cells through a TLR2-dependent mechanism. Nat Immunol. 2001;2.

16. Hung CC, Chang CT, Tian YC, Wu MS, Yu CC, Pan MJ, et al. Leptospiral membrane proteins stimulate pro-inflammatory chemokines secretion by renal tubule epithelial cells through toll-like receptor 2 and p38 mitogen activated protein kinase. Nephrol Dial Transplant. 2005;21(4):898-910.

17. Hung CC, Chang CT, Chen KH, Tian YC, Wu MS, Pan MJ, et al. Upregulation of chemokine CXCL1/KC by leptospiral membrane lipoprotein preparation in renal tubule epithelial cells. Kidney Int. 2006; 69(10):1814-22.

18. Chassin C, Picardeau M, Goujon JM, Bourhy P, Quellard N, Darche S, et al. TLR4- and TLR2-Mediated B Cell Responses Control the Clearance of the Bacterial Pathogen, Leptospira interrogans. J Immunol. 2009;183(4): 2669-77.

19. Hsu SH, Lo YY, Tung JY, Ko YC, Sun YJ, Hung CC, et al. Leptospiral outer membrane lipoprotein LipL32 binding on toll-like receptor 2 of renal cells as determined with an atomic force microscope. Biochemistry. 2010;49(26):5408-17.

20. Leemans JC, Stokman G, Claessen N, Rouschop KM, Teske GJD, Kirschning CJ, et al. Renal-associated TLR2 mediates ischemia/reperfusion injury in the kidney. J Clin Invest. 2005;115(10):2894-903.

21. Inthasin N, Wongprompitak P, Boonwong C, Ekpo P. Role of Toll-like receptor 2 in mediating the production of cytokines and human beta -defensins in oral mucosal epithelial cell response to Leptospiral infection. Asian Pac J Allergy Immunol. 2019;37(4):198-204.

22. Guaní-Guerra E, Santos-Mendoza T, Lugo-Reyes SO, Terán LM. Antimicrobial peptides: General overview and clinical implications in human health and disease. Clin Immunol. 2010;135(1):1-11.

23. Jansen PAM, Rodijk-Olthuis D, Hollox EJ, Kamsteeg M, Tjabringa GS, de Jongh GJ, et al. $\beta$-Defensin-2 Protein Is a Serum Biomarker for Disease Activity in Psoriasis and Reaches Biologically Relevant Concentrations in Lesional Skin. PLoS One. 2009;4(3):e4725.

24. Senavirathna I, Rathish D, Agampodi S. Cytokine response in human leptospirosis with different clinical outcomes: a systematic review. BMC Infect Dis. 2020;20(1):268.

25. Papa A, Kotrotsiou T. Cytokines in human leptospirosis. Trans Roy Soc Trop Med Hyg. 2015;109(12):749-54.

26. Sitprija V, Pipatanagul V, Mertowidjojo K, Boonpucknavig V, Boonpucknavig S. Pathogenesis of renal disease in leptospirosis: Clinical and experimental studies. Kidney Int. 1980;17(6):827-36.

27. Athanazio DA, Silva EF, Santos CS, Rocha GM, Vannier-Santos MA, McBride AJ, et al. Rattus norvegicus as a model for persistent renal colonization by pathogenic Leptospira interrogans. Acta Trop. 2008;105.

28. Ko AI, Goarant C, Picardeau M. Leptospira: the dawn of the molecular genetics era for an emerging zoonotic pathogen. Nat Rev Microbiol. 2009;7(10):736-47.

29. Lowanitchapat A, Payungporn S, Sereemaspun A, Ekpo P, Phulsuksombati D, Poovorawan Y, et al. Expression of TNF- $\alpha$, TGF- $\beta$, IP-10 and IL-10 mRNA in kidneys of hamsters infected with pathogenic Leptospira. Comp Immunol Microbiol Infect Dis. 2010;33(5):423-34.

30. Jansen PAM, Rodijk-Olthuis D, Hollox EJ, Kamsteeg M, Tjabringa GS, de Jongh GJ, et al. $\beta$-Defensin-2 Protein Is a Serum Biomarker for Disease Activity in Psoriasis and Reaches Biologically Relevant Concentrations in Lesional Skin. PLoS One. 2009;4(3):e4725. 
31. Matsui M, Roche L, Geroult S, Soupé-Gilbert M-E, Monchy D, Huerre $\mathrm{M}$, et al. Cytokine and Chemokine Expression in Kidneys during Chronic Leptospirosis in Reservoir and Susceptible Animal Models. PLoS One. 2016;11(5):e0156084.

32. Lehmann J, Retz M, Harder J, Krams M, Kellner U, Hartmann J, et al. Expression of human beta-defensins 1 and 2 in kidneys with chronic bacterial infection. BMC Infect Dis. 2002;2(1):20.

33. Chang MY, Cheng YC, Hsu SH, Ma TL, Chou LF, Hsu HH, et al. Leptospiral outer membrane protein LipL32 induces inflammation and kidney injury in zebrafish larvae. Scientific Reports. 2016;6(1):27838.

34. Smith KD. Toll-like receptors in kidney disease. Cur Opin Nephrol Hypertens. 2009;18(3):189-96.

35. Agace WW, Hedges SR, Ceska M, Svanborg C. Interleukin-8 and the neutrophil response to mucosal gram-negative infection. J Clin Invest. 1993;92(2):780-5.
36. Gerritsma JS, Hiemstra PS, Gerritsen AF, Prodjosudjadi W, Verweij CL, Van ES LA, et al. Regulation and production of $I L-8$ by human proximal tubular epithelial cells in vitro. Clin Exp Immunol. 1996;103(2):289-94.

37. da Silva Junior G, Srisawat N, Galdino G, Macedo, nio, et al. Acute kidney injury in leptospirosis: Overview and perspectives. Asian Pac J Trop Med. 2018;11(10):549-54.

38. Fruitwala S, El-Naccache DW, Chang TL. Multifaceted immune functions of human defensins and underlying mechanisms. Semin Cell Dev Biol. 2019;88:163-72.

39. Yamaguchi Y, Ouchi Y. Antimicrobial peptide defensin: identification of novel isoforms and the characterization of their physiological roles and their significance in the pathogenesis of diseases. Proc Jpn Acad Ser B Phys Biol Sci. 2012;88(4):152-66. 